\title{
Does the Newly Shaping Structure in Energy Sector Mean a New Order for the World?
}

\author{
Asst. Prof. Dr. Onur Tutulmaz (Hitit University, Turkey)
}

\begin{abstract}
The recent developments bring US to a major natural gas and oil producer position. The attempts in last 20 years to bring new horizontal drilling and hydraulic fracturing technologies together have developed a success in shale gas and oil production in US; the production volumes has reached to a position to redefine the market. Last estimations are bringing more information about the shale capacities of the major basins of the world. However, the estimates are based on a wide range of assumptions and consequently their results vary in a large scale. In any case, these developments have crucial economic, political and geopolitical consequences on the energy market, petroleum producer and consumer countries and regions. Despite the wide range of ambiguity of the estimated size of the resources, the estimations show US and North America has one of the biggest potential, already turning technology into the giant production numbers. Some of the estimations allege so big numbers can even mean to a new world order. The asymmetric nature of the potential, can also be said, increases some of the expected impacts too. In this study, basically, we want to supply an initial solid and economical evaluation to this ambiguity. We are trying to shape a frame for the new energy potential and to put it in a place in the current practice of the world. Secondly, in this context, we are underlying here some of the possible economic and geopolitical consequences each of which can constitute a subject of deeper study.
\end{abstract}

\section{Introduction}

When the reports of a 'new gold rush' started to be aired in 2011 (Economist, 2013, p.) it raised questions to what extent its size can reach. There are some voices that claim a big revolution for world economy with referencing the substantial oil and gas production rise has been experienced in USA (see, Morris, 2013; IEA, 2012). It is not easy to calculate how far the results of this new boom of energy production can be reach.

Energy has always been important for the economy and politics. There have been extensive political struggle for the energy reserves. The way of producing and consuming energy especially the fossil fuels which are highly dominant in the global economy and industry has been one of the important issues in this context. Economic development, technological innovations, industrialization and the new global issues (such as environmental issues) coming as its consequences have all mutual relationship with the energy concept; and make it more complicated and important for the current economic order of the planet.

Because the world economy is relying on mainly on the fossil fuels, the projection on its capacity or lifespan has been always important. Development and possible replacements of all other energy options, such as alternative and renewable energy, have been reckoned according to the availability and the capacity of the primary option.

Because of these reasons, any change in this structure will have butterfly effects to industries and economies. The production boom in US suggests that kind of change has been already happening right now. Its results are already started to change the energy structure in America. The projections show that USA is about to being the biggest oil producer in the world. This change came very fast. To that extend the ambiguity on the final shape of the changing picture is extremely large. For example, after seeing and evaluating the first years of the shale gas and oil boom, Lieber (2012) can foresee just a substantial reduction in oil imports of US; while, others such as EIA reports can mention about an energy independency or a net energy exporter status for US in near future (see, EIA, 2014). IER (2011) estimates even more excessive resources, extends this suggested energy independency up to the level of centuries. The one thing which is crystal clear is that the claims about the changing situation and its possible results need to be brought into academic discussion.

The mentioned estimates are not only to change the capacity profile of the primary energy source but also deem to change the whole energy perspective. To that extend it is expected to have most important effects on economic, political, geopolitical effects. In this paper, trying to draw a macro frame for the size of the new energy opportunity, we try to evaluate it in the present global energy picture and suggest or estimate an importance of it. Conducting this type of premier suggestion we also want to call for further studies on the very important sequential areas. Second section borders the global energy picture in which we will evaluate the importance of the new developments. Third section tries to give the notion on the origins of the new boom. Section four conducts the quantitative and economic evaluation. Fifth section concludes the paper.

\section{Energy Structure of the World}

The primal source of energy of the world comes from the sun. The total annual solar energy the earth is exposed to is approximately $5400 \mathrm{Q}$. The estimations about the amount of carbon processed via photosynthesis 
show about $5 \times 1010$ tones equal roughly 20 Q energy. It equals roughly $0.4 \%$ of the earth's annual solar energy intake (Bolton, 1978, p.181).

Total world proved natural gas reserves have almost tripled (see, Figure) to 6793 tcf in last 30 years (OGJ, 2012). Similar discoveries have also happened for oil reserves updating the numbers upward in the history (for example US has so far consumed 2.5 times much of the oil that is predicted as its total reserves 30 years ago, see IER, 2011, p.1) Total world proved oil reserves are 1342 billion barrels (IER, 2011, p.2). We can add roughly 1000 billion short tons coal to this picture, almost half of the recoverable resources being in US. These reserves are predicted to have potential to enlarge from 2 to 70 times for the North America case (see, IER, 2011) using the new developing technologies; this last argument is rather disputable and is discussed in Section 4.

The world annual primary energy usage is over 500 quadrillion Btu for the year 2010 (EIA, 2012); with almost $1 / 5$ of it belonging to US consumption alone. About a $4 / 5$ of the primary energy consumption is met by fossil fuels.

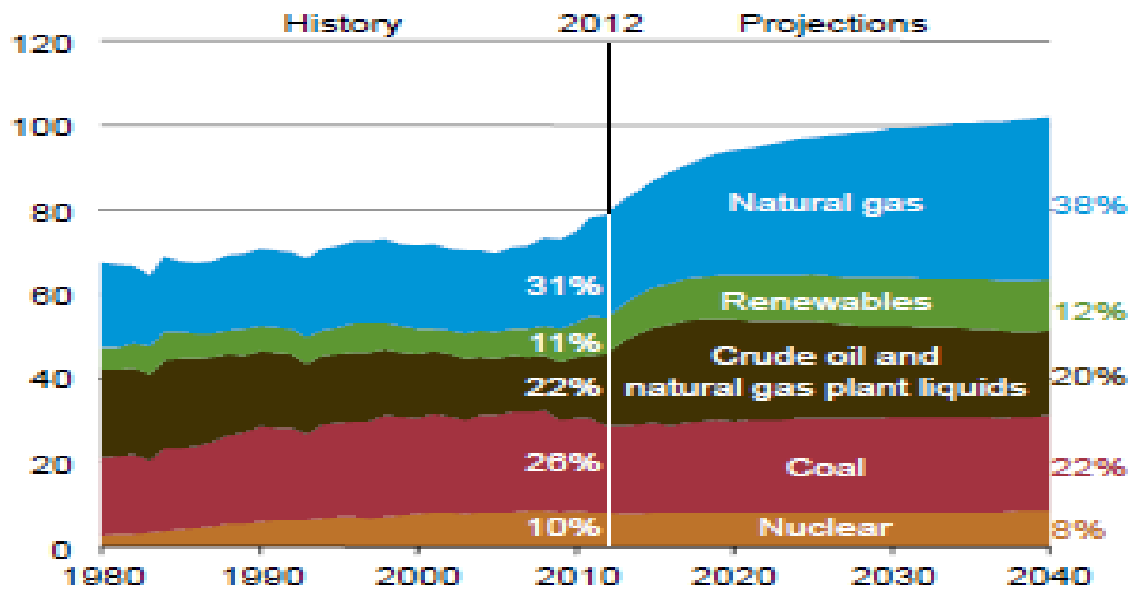

Figure 2. Variety in energy production in US, 1960-2040 (quadrillion Btu) Source: EIA, 2014

As the numbers show that there is a big potential in terms of alternative energy resources. The environmental issues, national and international regulations will be the determining factor for this potential. On the top of that, there is technological factor changing all parts of this equation. It is highly possible that the increasing usage of the alternative and renewable energy sources might trigger further new technological developments in these areas. However, as can be seen in Figure 2, a dramatic change is not expected in energy production scales in 30 years.

In this global picture, a quick macro level calculation will show that the world's proven reserves can supply energy roughly for 40-50 years, without taking the new potential capacity into account. However, especially the short-term technical constraints and the 'peak oil' discussion on rising demand of oil shows the biggest pressure will be on oil supply part (for different views of discussion, see Hoong, 2012, pp.231-33; JFCOM, 2008, p.28; IEA, 2008). Regarding to that aspect, as Figure 2 and EIA predictions suggest, it can be expected a natural gas replacement to certain degree (see EIA, 2014, p.12-13).

\section{Where Does Boom Come From?}

Fossil fuels derive from decayed plant and animal matter trapped within the earth for hundreds of millions of years (Morris, 2013, pp. 18-19). Dead organic material accumulated under water and forms mud. Mud was compressed into sedimentary shale rock in time. This geologically slow process leads a transformation of the organic material to hydrocarbons, chains of carbon and hydrogen atoms.

Conventional oil reservoirs form if the liquid or gaseous hydrocarbons pass, by time, from the shale to a reservoir medium (or in some cases directly to the surface of the world). Shale rocks have been, however, stayed as unfeasible to exploit so far because they are generally formed as thin layers situated very deep in the earth.

The technological advancement to change this fact came by the private American engineering attempts that unite the new technological developments of directional drilling and hydraulic fracturing into a replicable final engineering solution for shale well drilling. An important stimulus for this success can be proposed as the private mineral right ownership in America: in America, different from the most of the countries, mineral rights are associated to the land and belong to landowners. As a result of this technology becoming available we have been experiencing a substantial increase in shale oil and gas production in America. Moreover, in the light of the new developments. 
The similar technological developments also bring 3 other potential sources of unconventional gas and oil to the agenda: coalbed gases, oil sands and tight oil (oil shale). Some of them already started to be processed; however, they are not consisting comparable volumes as shale gas and oil is. Therefore, they are not assumed to either to have capacity to change the general picture of the global energy, nor are they calculated in the forecasts regarding to reckoning the new potential.

\section{Evaluations of Potential}

How big units we are talking about? What can be the economic value of this new imminent energy production boom? Of course, these questions depend on the quantitative estimations about the geological reserves and the qualitative estimations of these reserves. The quantitative estimations are not consistent and give a very cloudy picture us for the moment. In this scarcity of reliable data, for example, US Energy Information Administration's (EIA) estimations in same year, 2012, could be $\% 50$ different from each other. Having this in mind, we need to draw a quantitative and economic borders for the new energy opportunity we are being faced.

\subsection{Technical Evaluations}

The primary energy consumption of US is 95 quadrillion BTU per year and is predicted to grow $12 \%$ by the year of $2040.82 \%$ of that consumption is coming from the fossil fuels and this proportion is expected to change by only a $2 \%$ decrease in next 30 years (EIA, 2014). The world's total primary energy consumption in 2010 is over 500 quadrillion BTU and almost the half of this consumption belongs to OECD countries. This consumption is predicted to increase to 820 quadrillion BTU and about $85 \%$ of it comes non-OECD countries, specifically China consists $40 \%$ of the total increase of primary energy consumption (EIA, 2013, Table A1).

So far, the consumption predictions are stable and seem having reliable projections in a viable range. The problem part lies in the resources part: the new shale drilling and fracturing technology created a new opportunity but the size of this potential is highly ambiguous. Below, we gave some examples of that variety.

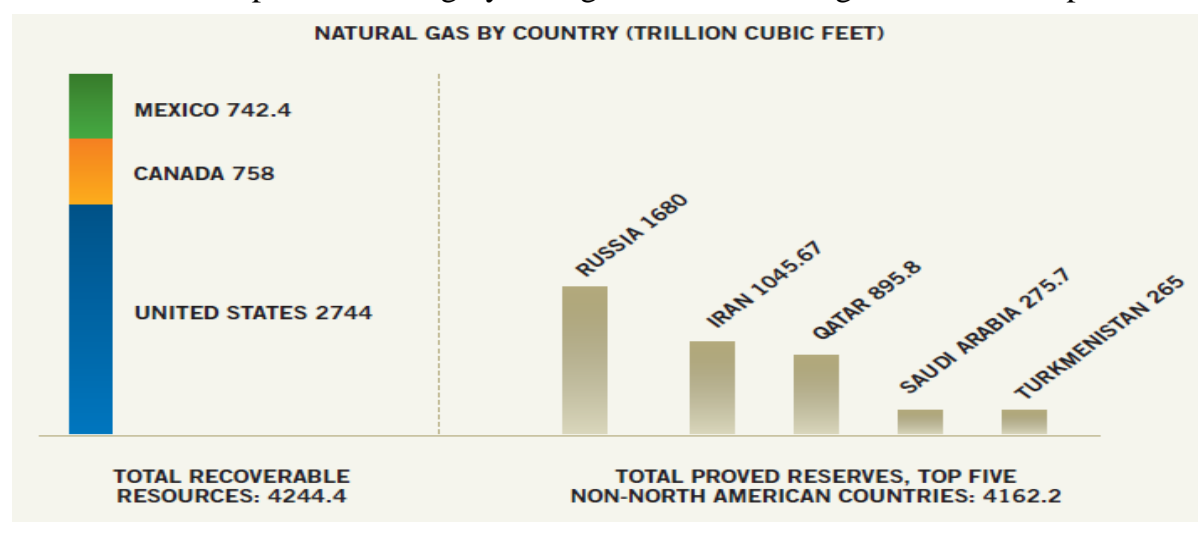

Figure 3. Natural Gas by Country (trillion cubic feet) Source: EIA, 2014

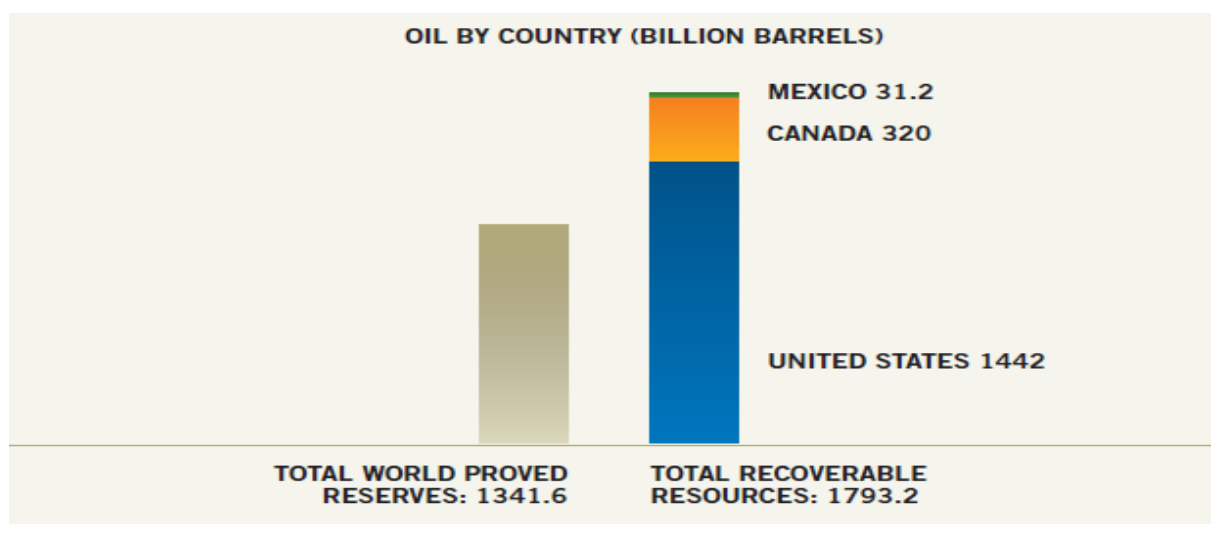

Figure 4. Oil by Country (billion barrels) Source: EIA, 2014

Starting with the global proven capacity we pictured in section 2, we see that the world proved natural gas and oil reserves have reached the level of $6793 \mathrm{tcf}$ and 1342 billion barrels respectively (see Section 2; Figure 3 \& 4). USA had a 20 billion barrel proven oil reserves until a few years ago. After the new technology comes into the scene, IER calculates that the technically recoverable natural gas and oil resources of US are 2744 tcf and 1442 billion barrel respectively. ARI (2011) estimated the world recoverable resources of shale natural gas as 5760 tcf; ARI (2013) updated it to 6634 tcf for natural gas and 335 billion barrels for shale oil. EIA (2013) estimated 7299 tcf of gas and 345 billion barrels of oil. ARI (2013) estimates the US will have biggest share for 
natural gas and second biggest share of oil in this total world potential: for shale natural gas and oil are 1161 tcf and 48 billion barrels respectively.

As we can see in a first glance, the capacity numbers for this new energy potential could by a factor of 2.5-3 times for gas and 28-30 for oil. The estimates and predictions are based on various assumptions. Therefore, this difference causes from several assumptions that the institutions take to conduct the estimations and predictions. First of all, based on the basin information institutes make a total resource potential prediction mainly based on assumptions. Secondly, the institution has to make an assumption on the percentage of this potential can be recoverable. These critical points seem to cause this wide range of variation in predictions. EIA's another assumption depending on the current technology is also shaping the forecasts by giving the advantage on the gas production side. Therefore, it seems that unless another technological development changes the situation, the gas production with shale production will be the dominant component in the energy forecasts.

Over $72 \%$ of petroleum are used in transportation vehicles and heating. Coal, natural gas and petroleum are currently responsible for $67 \%$ of global electricity production (ETC, 2011, p.59). These a few numbers can show how the current structure of the economy is directly depended to the fossil fuels. To change this dependency is the most important motive for the research and development activities on the alternative energy issues. However, the quick shifting efforts needs tremendous human intellectual capacity and come with the huge financial costs. Therefore, related with the new developments, a possible change in the perception of the emergency level of the need of any structural transformation will be crucially important for the future of all energy sectors.

\subsection{Economic and Political Consequences}

We can expect that there will be important consequences of any major technological shift in an important sector of the economy, especially if it contributes to understructures of other industries such as the energy sector. The most important results of the latest technological developments in the fracking and multidimensional drilling techniques can be pin down as economic, political and geopolitical. As for economic perspective, first of all, a huge economic potential has been revealed. It has already changed the macroeconomic calculations and predictions for USA economy. Just it was struggling the aftermath difficulties of the 2008 crisis, intellectual climate changed now calling to prepare itself to the next economic boom. This might continue in other geographies of the globe as the world's resources are being reevaluated; and also the updates in the prediction of the future of the world's biggest economy will change the predictions and near future plans of the other economies.

Another important economic change has come in terms of a change in comparatives in the energy economics. It is well known the reason that why hydrocarbons are being used as primary resource is their comparative cost advantage (Figure 5). The stimulus and investment budgets for alternative energy production have been based on mainly the idea of imminent scarcity of the fossil fuels as well as their adverse effects on environment primarily as carbon emissions. Therefore, any change in this perspective will change the projection on the spectrum once again.

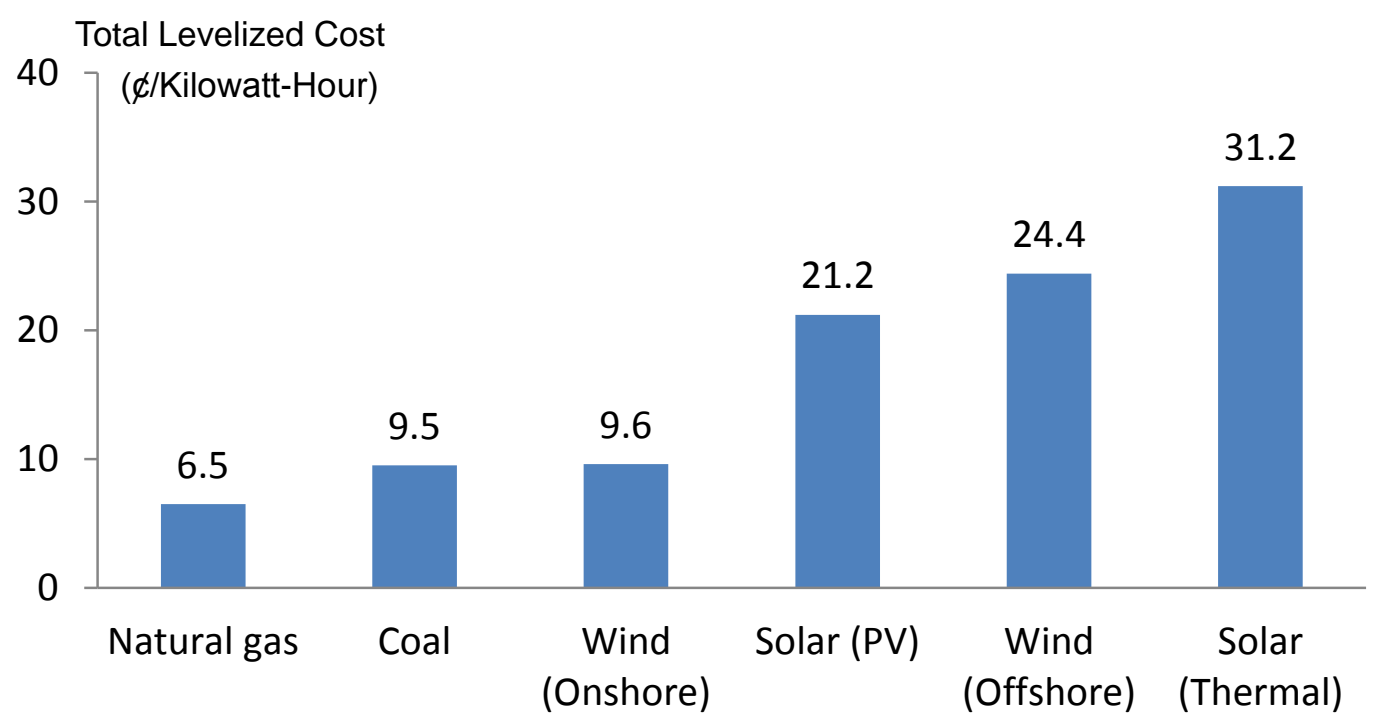

Figure 5. Total Levelized Cost by Energy Source

As the determination of energy spectrum is based on national and central decisions, the new projections on the primary energy resources will change the all plans and projections on the other energy tools. Because energy 
constitutes the main input of the manufacturing and transportation sectors, a change in energy macro-policies will also affect the investment decisions of these industries.

Another important effect can be classified as geopolitical change. The shale gas shift has not been obviously affect the other part of the world but even the changes have been happening (as well as the ones being projected) are enough to lead unprecedented changes in the international relations. America's imminent takeover the lead position in the energy production will make the continent energy independent. The shift of the world's biggest economy into the energy independent position means also a shift to political and geopolitical independencies because the relations of energy supply have been thought as the main factor in the geopolitics and international dependencies.

\section{Conclusion}

Some of the technological developments are brought together to shape this unconventional gas production boom we have been experiencing lately. The biggest effects so far have been in US energy production and US economy which was the start-off point itself; and it seems to continue growing. The predictions about the size of new potential vary from a capacity enough for few decades' consumption to one enough for more than century's annual energy consumption of US. It apparently implies that a big change is imminent in a lot of area starting from the energy economics and comparatives to energy politics and geopolitics.

The wide range of the projections about its possible effects will be clearer with coming information. Hovewer, the situation especially in US seems the action speaks first, production numbers rise and the predictions come later following the new numbers and discovered potentials. In this situation, a possible cost-benefit evaluation for the other producers and potential investors stays ambiguous and not feasible forcing them to a waiting position in the reshaping market.

There is bigger uncertainty about the direct and indirect results of this new imminent boom on the other part of the globe. In this aspect, we can evaluate that the biggest effects will be on the Middle East and Central Asia that include the other main oil and gas producers.

\section{References}

- AGA (2014). How to Measure Natural Gas. American Gas Association. Available at: http://www.aga.org/KC/ABOUTNATURALGAS/ADDITIONAL/Pages/HowtoMeasureNaturalGas.aspx.

- ARI (2013). EIA/ARI World Shale Gas and Shale Oil Resource Assessment. Advanced Resources International Inc, Arlington, USA.

- Bolton, J.R. (1978). "Photochemical storage of Solar Energy". Solar Energy, 20, 181-183.

- Economist (2013). "There's gold in them there wells". The Economist, December 21, 2013. Available at: http://www.economist.com/news/christmas-specials/21591748-theres-gold-them-there-wells

- EIA (2011). World Shale Gas Resources: An Initial Assessment of 14 Regions Outside the United States. United States Energy Information Administration-EIA, Washington, DC, USA.

- EIA (2012). International Energy Statistics. United States Energy Information Administration-EIA, Washington, DC, USA. Available at:

http://www.eia.gov/cfapps/ipdbproject/iedindex3.cfm?tid=44\&pid=44\&aid=2\&cid=ww,\&syid=2008\&eyid= 2012\&unit=QBTU. Date: 03.02.2014.

- EIA (2013). Annual Energy Outlook 2013. United States Energy Information Administration-EIA, Washington, DC, USA.

- EIA (2014). Annual Energy Outlook 2014 Early Release Overview. United States Energy Information Administration-EIA, Washington, DC, USA.

- ETC (2011). Earth Grab: Geopiracy, the New Biomassters and Capturing Climate Genes. ETC Group, Pambazuka Press, Oxford, UK.

- Hoong (2012). Singapore, the energy economy: from the first refinery to the end of cheap oil. 19602010. Routledge, New York.

- IEA (2008). World Energy Outlook 2008. International Energy Agency, Paris.

- IEA (2012). Golden Rules for a Golden Age of Gas: World Energy Outlook Special Report on Unconventional Gas. International Energy Agency (IEA)/Organization of Economic Coordination and Development (OECD), Paris. Available at http://www.iea.org/media/WEO_

GoldenRules_ForA_GoldenAgeOfGas_Flyer.pdf

- IER (2011). North American Energy Inventory. Institute for Energy Research, Washington, D.C.

- JFCOM (2010). Joint Operating Environment. United States Joint Forces Command. http://www.jfcom.mil. December 20, 2013. 
- Lieber, R.J. (2012). Power and Willpower: Why The United States Is Not Destined to Decline. Cambridge University Press, New York.

- Morris, C.R. (2013). Comeback: America's New Economic Boom. PublicAffairs, New York.

- OGJ (2012). "Worldwide look at reserves and production". Oil \& Gas Journal. 12 (110), 28-31.

- SCC (1979). Roads to Energy Self Reliance. Science Counsil of Canada. Ottawa, Canada.

- Trembath, A. (2012). Where the Shale Gas Revolution Came From: Government's Role in the Development of Hydraulic Fracturing in Shale. Breakthrough Institute Energy \& Climate Program.

- USGS (2000). USGS World Petroleum Assessment 2000, Description and results. United States Geological Survey Digital Data Series 60. United States Geological Survey. Available at: http://pubs.er.usgs.gov/publication/ds60; http://energy.cr.usgs.gov/WEcont/chaps/AR.pdf 